\title{
AN INTRODUCTION TO \\ ALTERNATIVE DISPUTE RESOLUTION
}

\section{JOANNE GOSS}

The author begins with a brief overview of the history and critical importance of alternative dispute resolution, or $A D R$. What follows is an indepth and practical survey of various methods of ADR. For each, the author introduces the method, its history and terminology and then lists its benefits and drawbacks. This introduction serves as a comprehensive practical reference tool for practitioners, as well as laying the groundwork for many of the articles which follow.
$L$ 'auteur offre d'abord un bref apercu de l'histoire et de l'importance critique du règlement de différends sans recours aux tribunaux (ou $A D R$ ). Suit un inventaire détaillé et pratique des diverses méthodes d'ADR. L'auteur présente chaque méthode, son historique et sa terminologie propre, et la liste de ses avantages et inconvénients. Cet article fournit un solide outil de référence aux praticiens et une excellente introduction aux nombreux articles qui suivent.

\section{TABLE OF CONTENTS}

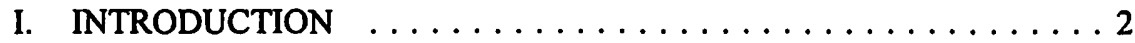

II. NEGOTIATION $\ldots \ldots \ldots \ldots \ldots \ldots \ldots \ldots \ldots \ldots \ldots \ldots$

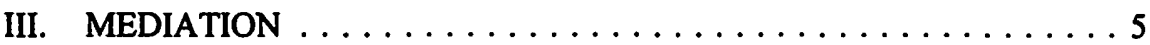

A. INTRODUCTION $\ldots \ldots \ldots \ldots \ldots \ldots \ldots \ldots \ldots \ldots$

B. UNDERSTANDING THE ISSUES IN DISPUTE $\ldots \ldots \ldots \ldots 7$

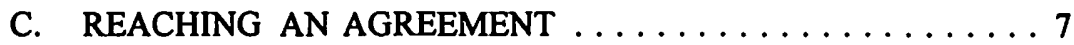

D. NO REGULATION OF MEDIATORS $\ldots \ldots \ldots \ldots \ldots \ldots 10$

IV. CONSENSUS BUILDING AND

NEGOTIATED RULEMAKING $\ldots \ldots \ldots \ldots \ldots \ldots \ldots \ldots$

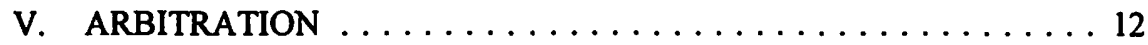

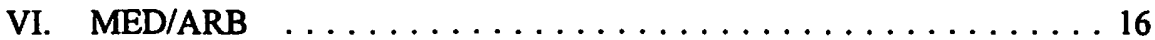

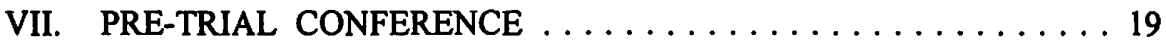

VIII. EARLY NEUTRAL EVALUATION $\ldots \ldots \ldots \ldots \ldots \ldots \ldots 22$

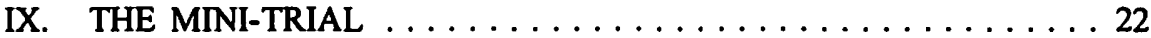

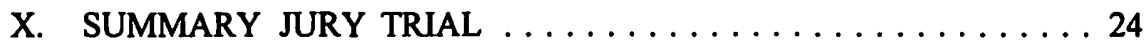

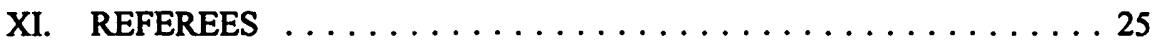

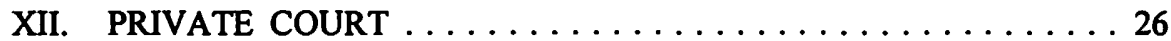

XIII. NEUTRAL EXPERT FACT FINDING $\ldots \ldots \ldots \ldots \ldots \ldots 28$

XIV. CONFIDENTIAL LISTENING $\ldots \ldots \ldots \ldots \ldots \ldots \ldots \ldots 28$

XV. APPRAISAL/VALUATION $\ldots \ldots \ldots \ldots \ldots \ldots \ldots \ldots 28$

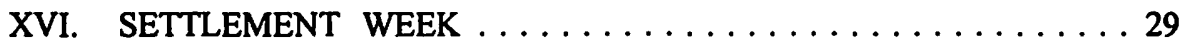

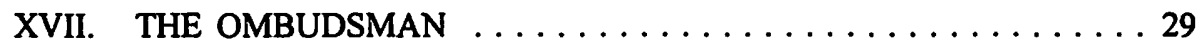

XVIII. LITIGATION MANAGEMENT $\ldots \ldots \ldots \ldots \ldots \ldots \ldots \ldots 31$

XIX. DISPUTE PREVENTION $\ldots \ldots \ldots \ldots \ldots \ldots \ldots \ldots \ldots \ldots \ldots \ldots$

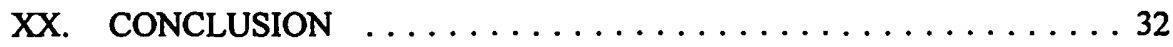

XXI. APPENDIX $\ldots \ldots \ldots \ldots \ldots \ldots \ldots \ldots \ldots \ldots \ldots \ldots \ldots \ldots \ldots \ldots \ldots$ 


\section{INTRODUCTION}

The key to success in a competitive global economy is the ability to resolve conflict effectively, according to Canadian futurist John Yerxa.' Indeed, with new products coming onto the international marketplace at the rate of five per day, the slow pace of litigation as a means of dispute resolution can be crippling. ${ }^{2}$ The drive for increased efficiency is unparalleled today both in the private and the public sector, as business and government move toward consolidation and streamlined "one stop" service, in an attempt to achieve "more for less." An area screaming for reform (and showing tremendous results in those corporations and government departments and agencies where it has been reformed) is conflict resolution. No longer can executives, officials and employees be tied up in expensive and time-consuming litigation except in very special circumstances. There is a better way.

Alternate Dispute Resolution, or ADR, as it is more commonly known, refers to the wide variety of methods by which conflicts and disputes are resolved other than through litigation. There is nothing particularly new or innovative about the alternate processes, however interest in and creative applications of these alternatives has exploded in the last quarter century. In the 1960s, interest in ADR started in the United States as an extension of the legal reform movement seeking to improve the legal justice system. ${ }^{3}$ The three principle goals of the ADR movement were:

1. to make the regular court system more efficient, less costly and more responsive to the needs of litigants;

2. to offer alternative methods of dispute resolution in addition to the regular court system; and

3. to provide public education about the available alternatives. ${ }^{4}$

Through the 1960s and 1970s these goals were slowly met as academics, legislatures, funding sources, the judiciary, the bar and the public became increasingly aware of and interested in ADR.

In 1988 the Canadian Bar Association established a Task Force on ADR chaired by the well known Canadian ADR practitioner, Bonita Thompson, Q.C., with the following goals:

1994 Yerxa Report.

2 A Business Week/Harris Executive Poll of top executives at corporations drawn from the Business Week top one thousand found that 62 percent of those surveyed believe that the U.S. civil justice system significantly hampers the ability of American companies to compete with Japanese and European rivals. 83 percent said the fear of lawsuits has more impact on decision making within their company today then it did ten years ago - "The Verdict from the Corner Office" Business Week (13 April 1992) 66.

$3 \quad$ S.B. Goldberg, E.D. Green \& F.E.A. Sander, Dispute Resolution (Toronto: Little, Brown and Company, 1985) at 4.

E.G. Tannis, Alternate Dispute Resolution That Works! (North York, Ont.: Captus Press, 1989) at 7 . 
(a) to develop an information bank for Canadian lawyers on where ADR has been developed to date and its status in this country;

(b) to provide the Canadian Bar Association with the information to permit a response to ADR developments in Canada, and to ensure that the development of ADR as an alternative or adjunct to our justice system occurs in an orderly, responsible and effective manner;

(c) to provide the Canadian Bar Association with a position on the future of ADR in Canada and to develop programs to encourage the proper and orderly development of ADR with the necessary input of the legal profession. ${ }^{5}$

In brief, the Task Force recommended greater integration of ADR within mainstream legal practice and legal education to ensure an informed and progressive legal community. In 1990, the Alberta Law Reform Institute published its first report on ADR, which advised the Alberta bar of methods and services available in Alberta; ${ }^{6}$ it now has a Special Series on Dispute Resolution.

The public also appears to be more aware of alternatives to the litigation process and the advantages of some of these alternatives. A survey commissioned by the Law Society of Upper Canada in January of 1992 found that 97 percent of those who responded to the survey felt it was a lawyer's obligation to make clients aware of alternatives for resolving legal problems other than going to court.' Familiarity with the merits of ADR processes is essential for practicing Alberta lawyers, as the Code of Professional Conduct states in the commentary to rule 16 of chapter 9: "In addition to the conventional legal process, a lawyer should consider alternative dispute resolution. ${ }^{.8}$ Lawyers and their clients must pay attention to the process of resolving conflicts and disputes as much as to the content of those conflicts and disputes.

The ADR movement does not advocate the abandonment of strategic decision making, it simply adds one more question into the equation: "How can I do the best, the quickest, the cheapest?" It does not advocate abandoning or replacing the judicial dispute resolution system, it simply means understanding the alternatives to litigation, their advantages and disadvantages, and considering how they can be most effectively utilized. ADR processes are also not mutually exclusive and can be used very effectively together. A continuum (see Appendix) is a very effective means of displaying the alternative processes available for dispute resolution, a few of which I will briefly describe in this introduction.

Canadian Bar Association, Alternate Dispute Resolution: A Canadian Perspective (Task Force Report) (Ottawa: Canadian Bar Foundation, 1989) at 2.

6 Alberta Law Reform Institute, Dispute Resolution: A Directory of Methods, Project \& Resources (Research Paper No. 19) (Edmonton: Alberta Law Reform Institute, 1990) [hereinafter ALRI Report].

7 Subcommittee on Dispute Resolution, Report Summary (February 1993) at 1.

8 Law Society of Alberta, Code of Professional Conduct (Calgary: LSA, 1995) at 102. 


\section{NEGOTIATION}

Negotiation is the method by which disputes are most often resolved. It involves discussions directly between disputing parties or their representatives which take place on a voluntary basis. A resolution to the dispute is reached only if all parties agree.

At the same time the ADR movement started to gather steam and attract the interest of academics, funding bodies and those directly involved in the resolution of disputes, a similar surge in interest and hunger for understanding the negotiation process was emerging. Academics began to study the process of negotiation to both demystify it as a skill and to understand it better as a process. ${ }^{9}$ Their research is showing that there are ways of increasing efficiencies in negotiation, simply by changing the approach to negotiations. Because so much of ADR involves negotiation, the two developments became quickly linked, thereby propelling the entire movement further forward.

Skill and success at negotiating a resolution to a conflict or dispute has many clear advantages:

- Satisfaction - The solution generated is the creation of the parties themselves.

- $\quad$ Speed - Negotiations can be commenced and concluded at any time, allowing for quick resolution of the dispute.

- Cost - Both time and money can be saved if the matter is resolved quickly.

- $\quad$ Privacy - Negotiations usually take place in private, on a without prejudice basis.

- Relationship - Negotiations can lead to an improvement in the business or social relationship of the parties involved in the negotiations, thereby yielding benefits over and above the simple resolution of the conflict or dispute.

The perceived limitations of the negotiation process are as follows:

- Ineffective - Negotiations are often not conducted seriously or effectively by one or both parties. Frequently, negotiations break down prematurely.

- Escalation of the Conflict - Negotiations often do not take place in a controlled environment and can therefore result in escalation of emotions and of the conflict.

- Delay - If unsuccessful, negotiations can cause delay. 


\section{MEDIATION}

Mediation is a process of dispute resolution focused on effective communication and negotiation skills. The mediator acts as a facilitator assisting the parties in communicating and negotiating more effectively, thereby enhancing their ability to reach a settlement. It is not the mediator's role to adjudicate the issues in dispute and indeed the mediator has no authority to do so. Mediation is not a process to force compromise, although compromise is an element of the process. Each party's limitations are respected and a party is only expected to make a shift in its approach to the problem if it becomes convinced that it is reasonable to do so.

Dispute settlement with the assistance of a third party has been utilized for centuries within many cultures and countries. Many years ago, the classical Chinese viewed mediation as superior to litigation, and African societies used "tribal moots" to resolve community disputes long before the imposition of colonial law. ${ }^{10}$ Today, mediation is the most rapidly growing form of ADR. It is being actively utilized in almost every conceivable type of dispute resolution and comes in various forms. The process has also been effectively adapted for multiple party dispute resolution with tremendous success. On average, the success rates of mediation processes range from 80 to 85 percent. " In an attempt to capitalize on the success rates, legislation is slowly being amended to include provisions for mediation of disputes.

A question often asked of mediators is how a mediator can help negotiations. Effective negotiations are dependent upon good communication and the utilization of effective negotiation techniques. Often, parties involved in direct negotiations may be lacking in one area or another, or may find it difficult to focus on both what is being negotiated as well as how the negotiations are being conducted. The advantage which a mediator can offer is to introduce an individual whose sole purpose in the negotiation process is to ensure that the parties are communicating and negotiating effectively. Essentially, the focus of the mediator is on the process of communication and

F.S.C. Northrop, "The Mediational Approval Theory of Law in American Legal Realism" (1958) 44 Va. L. Rev. 347 at 349; R. Danzing, "Toward the Creating of a Complementary, Decentralized System of Criminal Justice" (1973) 26 Stanford L. Rev. 1 at 42-3.

1 Statistical information obtained from Conciliation \& Mediation Services, Manitoba Labour in August of 1991 shows that since 1985, when the Manitoba Labour Relations Act was amended to provide for mediation, grievances have been settled through mediation with a settlement rate of about 85 percent. Also, the Mediation Research \& Education Project, Inc. (MREP) in Chicago, Illinois has mediated over 1,500 grievances since 1980 in the airline, secondary and university education, coal, copper, electric power, manufacturing, mass transit, municipal government, oil, refining, retail sales and telephone industries and report a success rate of 86 percent. This information was obtained directly from MREP in August 1991. The four divorce mediation programs studied and reported on to the Department of Justice in 1989 found a 75 percent success rate. Those who participated in mediation also perceived the process to be very effective. Edmonton Community mediation has a 93 percent success rate (per Peggy Dodson, Director of Community Mediation). Mediations conducted with the Insurance Corporation of B.C. (ICBC) on personal injury matters enjoy a 95 percent success rate to December 31,1990 (Everard, "Maximizing Dispute Resolution Alternatives: The Barristers Perspective" in Effective Dispute Resolution, New Horizons (LESA, 1991) at 6). 
negotiation being utilized by the parties in their interactions. The mediator will interject to ensure that the most effective negotiation approaches are being taken and that, if there is room for an agreement, that agreement is achieved.

Mediators generally approach the mediation process in a series of progressive steps which move the parties effectively through the various stages of a negotiation process. Generally, the approach is as follows:

\section{A. INTRODUCTION}

Initially in mediation the mediator will explain to the parties the process of mediation, the role of the mediator as facilitator (not adjudicator), and the role of the parties in working towards a solution. The mediator will attempt to create an atmosphere where the parties can feel free to discuss the issues in dispute between them openly. Some of the rules or guidelines which are generally incorporated into mediation processes as they assist in ensuring that the mediation process is as effective as possible are as follows:

\section{Voluntariness}

In mediation, as with any negotiation, the parties are not required to accept any resolution which is proposed, and they should accept only those resolutions which each feel are fair and reasonable. Alternatively, if an agreement cannot be reached on any or all of the issues, the dispute can proceed along the dispute resolution continuum to alternate processes.

\section{Confidentiality}

Mediation has the highest chance of leading to effective resolution of a dispute where the discussions take place in confidence. Confidentiality of mediation does not mean that otherwise producible evidence is thereby privileged, but simply means that negotiations will take place on a without prejudice basis. Therefore, offers and concessions that one party may have made during the mediation process cannot later be raised if the mediation is unsuccessful. The mediator is, of course, under strict confidence.

\section{Privilege}

The mediator should be granted a voluntary privilege whereby it is agreed between the parties or it is a rule of the mediation that the parties will not subpoena the mediator to testify at a later adjudicator process, should the issue proceed to adjudication. This helps to build trust in the mediator and give the mediator greater latitude in working with the parties. 


\section{B. UNDERSTANDING THE ISSUES IN DISPUTE}

The next two phases of the mediation process involve all of the parties having an opportunity to present their perspective on the issues in dispute to the other parties and the mediator, with the mediator attempting to ensure clarity. The mediator will work to clarify each party's understanding of the facts as well as to identify assumptions with the parties that are not based upon fact and are not reliable for decision making. The mediator will also identify common ground between the parties, isolating what the parties agree upon and what they do not agree upon. In general, the mediator attempts to narrow the dispute down to its basic elements to make the process of generating possible solution ideas as variable as possible. Specifically, the mediator will focus the parties on their needs and interests and the reasons behind what they want, as opposed to what they say they must have. The mediator will also attempt to ensure that each party is understanding the dispute from the perspective of the other party as well as understanding their underlying needs and interests. This is an essential prerequisite to the final stage of mediation where the parties in dispute attempt to come up with a way of resolving the issues effectively.

\section{REACHING AN AGREEMENT}

The final stage of mediation involves the mediator working with the parties to find a solution which is agreeable to each of them. Having already worked with the parties and developed an understanding among them of the perspective, needs and interests of the other party in the dispute, the mediator will at this point encourage the parties to brainstorm ideas, on a noncommittal basis, for how the needs and interests of both sides to the dispute could be met. This creates a much broader basis for putting a solution package together, pulling various ideas together from the solution options that have been generated. The mediator will usually assist in developing solution ideas, but will refrain from controlling this process, as the parties who are involved in the dispute are much more capable of knowing what the essential elements to a workable, long-lasting agreement are. Generally, a mediator will not bend arms or lean on one party by telling them they are being unreasonable and that they should compromise because only the parties know what will work for them. However, the mediator will lean on the parties to ensure that, if they are going to walk away from a solution package that has been generated, the other options which are available to that party are clearly better than the solution which has been placed on the table.

The time required to complete mediation varies according to the complexity of the issues being discussed. It can take less time if the parties are well prepared and understand their rights and obligations. If fewer issues are being discussed, mediation can take less time. Mediation can also take longer if the parties are highly emotional, do not understand their rights and obligations or simply need to discuss the issues at a slower pace in order to understand them more clearly. The flexibility of the process allows the mediator to accommodate all of these differences and move the mediation along at a pace with which the parties can be comfortable. Furthermore, the mediator can ensure that the discussions continue to move forward and toward resolution of the issues. 
The benefits which have been identified with mediation are as follows:

- Effective Process - Mediation generally enjoys an 80 to 85 percent success rate.

- Better Results - The resolution is created by the parties and is therefore tailored to their specific needs. This tends to result in a lower incidence of breach of the agreement reached. ${ }^{12}$

- Speed - A mediation can be arranged in a relatively short period of time and has the effect of bringing settlement negotiations "to a head" much more quickly than negotiations directly between parties, resulting in a faster disposition. ${ }^{13}$

- Cost - Time, money ${ }^{14}$ and emotion can be saved through early resolution of the dispute. Furthermore, the cost of mediation can be included with taxable costs and disbursements payable to the successful party. ${ }^{15}$

C.J. Richardson, Court Based Divorce Mediation in Four Canadian Cities: An Overview of Research Results, a report prepared for the Department of Justice Canada (February, 1988) 43 and 48; and S.B. Goldberg, "Grievance Mediation" (1989) Negotiation Journal 13; J. Kelly, "Is Mediation Less Expensive? Comparison of Mediation and Adversarial Divorce Costs" (1990) 8:1 Mediation Quarterly 15 at 25: Allen Ponak, a professor in the Faculty of Management at the University of Calgary and a labour arbitrator stated "fact is, even the most well arbitrated agreement is not as good as a collective agreement negotiated by the parties. An arbitrator can never appreciate the nuances of the contract language as it applies to that workplace, never reach as good solutions as the parties can who are living the agreement themselves" in an article by M. Vicars, "Win-Win Bargaining: Keeping the Dialogue Alive," (1993) 2:1 Worksight 13 at 16. According to Ponak, the consequence of arbitration can be an agreement that is less workable, leads to more grievances and causes more hostility affecting the next round of bargaining.

13 Richardson, ibid. at $\mathbf{4 1 .}$

14 The average cost per grievance mediation conducted by MREP is $\$ 300.00$. This is less than 10 percent of the cost of an average arbitration. Also, research conducted in 1990 by J. Kelly, Past President of the Academy of Family Mediators, showed that in complex divorce cases the mean cost of the adversarial process for both the husband and wife combined was 134 percent higher than the costs of comprehensive mediation (mediation of all the issues). Even when the divorce was less complex, mediation was still less costly as adversarial clients spent 27 percent more than mediation clients to get their final divorce, supra note 12 . As concluded by J. Kelly "Because the two groups did not differ in the complexity of their divorces, the extent of reported marital conflict, the initial level of anger at spouses, cooperation at the beginning of divorce, the amount of anticipated disagreement about issues to be resolved, or in household income, the cost difference can be assumed to be a result of the differences in the processes themselves."

In the decision of Stimac v. Wasson (10 January 1991), Vancouver 393257 (B.C.S.C.) the Taxing Officer found that mediation fees paid during the course of litigation were to be included in the Bill of Costs as a necessary and proper expenditure. The agreement between counsel that the mediation fees would be split equally was not an agreement that precluded either party from passing on its half to the ultimately successful party after an order or agreement concerning costs was made. This agreement was deemed an "interim arrangement made in order to get the alternate dispute resolution procedure in motion." 
- Choice of Mediator - A mediator can be chosen who has expertise in negotiation, effective dispute resolution and in the particular areas of dispute. Such expertise may be of assistance to the parties in resolving the dispute.

- Problem Centred - The mediation process focuses on the interests and underlying concerns of the parties as opposed to their legal rights and remedies in searching for a resolution.

- Control - Each of the parties maintain control of the dispute and its resolution because they design the settlement and agree to live by it only if it is acceptable to them. ${ }^{16}$

- $\quad$ Privacy - Mediation takes place in private and therefore the details of the dispute and its resolution need not be publicly disclosed.

- Freedom to Negotiate - Because the process is confidential and takes place on a without prejudice basis the parties have the freedom to develop and consider innovative settlement ideas.

- Enhanced Negotiations - The focus of a mediator on the negotiation process can help keep the negotiations on track and moving forward.

- Informal Atmosphere - The informal setting and atmosphere of mediation is conducive to effective communication between the parties about what each needs in the agreement. ${ }^{17}$

- Improved Relationship - Mediation can preserve or enhance the relationship between the parties. ${ }^{18}$

- $\quad$ "Day in Court" - In mediation, the parties have a full opportunity to be heard and to vent the emotional side of the dispute. This process allows them to move toward considering settlement much more quickly than through indirect negotiations.

- Voluntary - The mediation process is entirely voluntary and accordingly, either party can leave the process at any moment should they feel that it is no longer progressing or that they are somehow being prejudiced by the process.

There are also drawbacks to mediation which need to be considered when looking at mediation as an alternative for resolving disputes:

$36 \quad$ Richardson, supra note 12 at 44.

17 J. Folberg \& A. Taylor, Mediation: A Comprehensive Guide to Resolving Conflicts Without Litigation (San Francisco: Jossey-Boss, 1988) at 296.

is Some of the mediation programs MREP have been involved with have lead to broader labourmanagement cooperation efforts according to the President of MREP, S.B. Goldberg, supra note 12 at 12. It was also described as a more humane approach to decision-making upon family breakup in Richardson, supra note 12 at 48. 
- Voluntariness - All parties to the dispute must agree to take part and actually take part in the process for it to be effective; it cannot be imposed. It is argued that it is therefore only a viable alternative where the parties are predisposed to settle.

- Power Imbalance - If a power imbalance between the parties cannot be neutralized during mediation and is rendering one of the parties ineffective as a negotiator, mediation should not proceed. ${ }^{19}$

- Formal Contract - Mediation itself does not generally generate a formal agreement. Lawyers are still necessary for this. However, the mediation process can generate the basis for agreement which simply needs to be formalized.

- Unofficial Discovery - Mediation can provide a means of obtaining further information about a dispute from the other parties.

- Delay - If unsuccessful it may have caused delay.

- No Precedent - Resolution of the dispute through mediation does not provide a precedent for the resolution of other disputes.

- Informal Justice - Some have criticized mediation in that it involves the resolution of disputes in private which may not adequately protect people's rights. $^{20}$ It is also criticized as providing "second class justice" for disadvantaged groups.

\section{NO REGULATION OF MEDIATORS}

In Alberta mediators are not regulated by a professional association or by the government; anyone can call him or herself a mediator without having the proper

W. Ury, Brett \& Goldberg, Getting Disputes Resolved (San Francisco: Jossey-Boss, 1988) at 17. Such an imbalance of power can exist (for example where domestic violence has taken place) and many argue that mediation should then not be attempted. A summary of these arguments is included in the Report of the Attorney-General's Advisory Committee on Mediation and Family Law (Attomey-General for Ontario, 10 February 1989) at 47 [hereinafter Attorney-General's Report]. Others argue that if domestic violence exists the mediator must help the couple put protections in place that will allow mediation to proceed. The Attorney-General's Advisory Committee concluded on p. 76 of its report that: "violence in and of itself [can] not be used as a means of excluding clients from the use of mediation services. The determinative matter is the effect of violence on the relative bargaining position of the clients. If domestic violence renders an individual incapable of negotiating with the other spouse, then mediation services would properly be denied." 
training or skills to do so. It is therefore imperative that counsel investigate the training and qualifications of potential mediators. ${ }^{21}$

Mediation can be agreed to as the method of dispute resolution under a contract, by way of a mediation clause. Where no such clause exists, mediation can be agreed to after a dispute arises by simply retaining a mediator with an agreement to mediate. Increasingly, large organizations and corporations are incorporating mediation as a process of dispute resolution internally by making internal mediators available or providing access to a mediation process. These resources are aimed at providing for the early resolution of disputes both within the company or organization or between that organization and external entities. These programs have had tremendous success where they are effectively implemented. ${ }^{22}$

\section{CONSENSUS BUILDING AND NEGOTIATED RULEMAKING}

Consensus building is a process of multi-party mediation in which all who have a stake in the outcome work together to maximize the opportunities and resolve the differences presented by a wide spectrum of values, viewpoints, expectations and limitations among the participants. The focus of the process is:

(a) initially, on information exchanged;

(b) then, on identifying and understanding differing perspectives, values, needs, concerns, aspirations, limitations and priorities; and

(c) finally, on problem solving, on discovering how the values, viewpoints and expectations can be reconciled or how differences can be exploited to create the optimum.

Consensus is reached if all participants are willing to support the total package. The goal of the process is to come up with a broadly supported final product. If the consensus is not reached on the entire package or at all, the decision maker proceeds to make a decision unilaterally. This opportunity to directly influence the final outcome is the impetus for each of the stakeholders to make compromises and reach consensus. The success of consensus building depends on the ability of all participants to communicate, negotiate, solve problems and keep working towards agreement.

See ALRI Report, supra note 6. In Richardson, supra note 12 at 17, it was shown that 71 percent of mediators hold a post-graduate degree and therefore the concern over inadequately trained mediators may not be as big a problem in reality as is perceived. In June of 1994, the Arbitrators and Mediators Institute of Canada established the Chartered Mediator designation which is based upon a certain level of education and training, experience and a skills assessment. These mediators, called Chartered Mediators, do adhere to a code of ethics. Furthermore, most provincial dispute resolution organizations have a code of ethics to which they ask their mediators to adhere. An option may be to specifically incorporate reference to those codes of ethics in any agreement to mediate or mediation clause in a contract.

22 T. Carver \& A. Vondra, "Alternative Dispute Resolution: Why It Doesn't Work and Why It Does" (1994) 72:3 Harvard Bus. Rev. 120. 
Generally, a facilitator or mediator will manage the process and assist individuals and the group as a whole to communicate, negotiate and problem solve effectively.

Negotiated rulemaking is simply consensus building applied to the development of rules and regulations. Essentially, industry stakeholders, government and members of the public with an interest in the area of concern come together in an attempt to negotiate the necessary rules and regulations for the particular industry or area of activity and influence. The goal is to come up with a set of rules and regulations which can be supported by the stakeholders who will be overseeing, implementing, living by and looking toward those rules and regulations for their governance, direction and protection. The process challenges the stakeholders to overcome differences, disputes and conflicting concerns by working towards improving the rules and regulations to meet those concerns, as opposed to taking adversarial approaches to influencing the decision makers.

\section{ARBITRATION}

Arbitration is a procedure for the resolution of disputes on a private basis. An arbitrator is an independent, neutral third person who hears and considers the merits of a dispute and renders a final and binding decision called an award. The process is similar to the litigation process because it involves adjudication; however, the parties choose their arbitrator and the manner in which the arbitration will proceed. For example, if the dispute is fairly straightforward and does not involve any factual questions, the parties may agree to waive a formal hearing and provide the arbitrator with written submissions and documentation only. That process is called a documentsonly arbitration. In other cases, the parties may wish for a full hearing. The parties create their own adjudicatory forum which is tailor-made to the particular needs of the parties and to the nature of the dispute.

Although arbitration has traditionally been associated with labour, commercial and international disputes, it is being increasingly used in smaller disputes and even in family matters. Indeed, a number of consumer-oriented programs have included arbitration as one of the alternate means by which the dispute can be resolved. ${ }^{23}$ Furthermore, legislation is increasingly referring to arbitration as an alternative to be considered. Once an arbitrator makes an award, that award can be enforced in the same manner as a judgment of the court pursuant to s. 49 of the Arbitration Act of Alberta. ${ }^{24}$

As in the case of mediation, arbitration can be agreed to as the method for dispute resolution under a contractual arrangement prior to any disputes arising or it can be agreed to once a dispute has arisen. There are many considerations in drafting arbitration clauses, particularly as light is increasingly shed on the new Arbitration Act through its judicial interpretation. 
The advantages of arbitration over court adjudication can include the following:

- Expertise of the Decision-Maker - The arbitrator is selected by the parties. Therefore, the parties can choose a decision-maker who has expert knowledge of the law, business or trade in which the dispute has arisen.

- Finality of the Decision - The arbitration process results in a final and binding award subject to a limited right of appeal, providing finality for the parties in dispute.

- Privacy of the Proceedings - Arbitration is held in private and no precedent is established by the decision-maker other than in labour arbitrations. Accordingly, if the parties wish their dispute and its resolution to remain private, arbitration can provide this privacy.

- Low Cost - Simplified procedures tend to reduce the cost of dispute resolution, especially if lawyers are not used. ${ }^{25}$ The lack of opportunity for appeal can also reduce the overall cost of dispute resolution.

- $\quad$ Speed - Arbitration can be arranged within days, weeks or months; therefore, if parties wish an immediate resolution to the dispute, arbitration can provide this. Such quick resolution can save costs in terms of time, money and energy. A very rough rule of thumb is that arbitration takes about $1 / 3$ to $1 / 8$ of the time it would take to have a matter disposed of in court. ${ }^{26}$

- Technical/Professional v. Legal Award - The awards generated through arbitration are generally less legal in nature and more or less technical, depending upon the subject matter of the arbitration. This may be appealing to parties who are embroiled in a technical dispute.

- Availability to State a Case - Should the arbitrator require a legal opinion from the court, the arbitrator or a party can "state a case" to obtain the court's ruling on the law.

- Facilitation of a Negotiated Settlement - The act of bringing the parties together in the preliminary stages of arbitration and isolating the areas of difference can frequently lead to a more calm, cooperative understanding among the parties. Furthermore, if the arbitrator is also given the ability to act

25 J. Daly, "Burying the Hatchet" (1994) 107:3 MacLeans 34 at 35; Costs of an arbitration are about $\$ 5,000-\$ 10,000$ for a two day complicated matrimonial property issue (G. Frolich, Address at the Family Law Refresher (Banff, May 1993) [unpublished]). 
as a mediator she may be able to assist the parties in coming to a negotiated resolution on some or all of the issues.

- $\quad$ Adaptability of the Process - An arbitration can be structured and designed to suit the nature of the problem and the parties involved. In some instances a hearing may be appropriate, while in other instances the arbitrator may review documents only. The parties may exercise complete control over the procedure to be applied in resolving their dispute either by specifying the procedure in the arbitration agreement or by meeting with the arbitrator at the preliminary meeting to set out a workable procedure.

- Convenience - Both the timing and location of arbitrations are arranged to suit the convenience of the parties.

- Enforcement - An arbitration award can be enforced as a judgment of the court.

- Counsel - Counsel, if utilized, need not be a member of the local bar, and non-lawyers can also be used to represent the parties.

- Creativity - Arbitrators can be authorized to fashion creative solutions to disputes.

The drawbacks associated with the arbitration process are as follows:

- Enforceability - The arbitrator's award can be effective only for or against the parties to the reference, and cannot be binding upon third parties. ${ }^{27}$ Parties to an arbitration can frustrate the arbitration process by adding parties and issues to the claim that are outside of the agreement containing the arbitration clause. $^{28}$

- Cost - Despite its promised speed, low cost, and informality, arbitration has been criticized as being increasingly slow, expensive and formal. This criticism is particularly poignant in the area of labour arbitration, where the average grievance arbitration case in Alberta takes $11 \frac{1}{2}$ to $191 / 2$ months from when the

"Any possible rights of third parties cannot be affected by an arbitration between the parties" per Master Funduk in Orlando Construction Ltd. v. Loyal Electric Lid. (15 June 1982), Edmonton 8203-09025 (Alta. Q.B.); and see Re: Matthews and Webster (1852), I P.R. 75. This was the problem facing the court in Kaverit Steel and Crane Lid. v. Kone Corp. (1992), 120 A.R. 346 (C.A.) (Kerans, Hetherington, and Irving, JJ.A.), an international arbitration under the Alberta International Commercial Arbitration Act, S.A. 1986, c. I-6.6. The Court of Queen's Bench had found that for these reasons the stay application should be denied and nothing should go to arbitration. On appeal, the Court of Appeal overturned the decision and split off those issues covered by the Arbitration Agreement over which a stay of proceedings was granted from those not covered, over which a stay was not granted. Mr. Justice Kerans stated at 353: "the agreement to arbitrate should be honoured and enforced whether or not the plaintiff displayed great imagination in the pleadings." 
grievance is filed to the issuance of an award, and the costs with three party arbitral tribunals can be excessive. ${ }^{29}$

- Compromise - It is frequently alleged that there is incentive for an arbitrator not to act impartially but to compromise or to favour one side. ${ }^{30}$

- No Appeal - Unless the arbitration agreement provides for expanded grounds of appeal, the only appeal from an arbitration award is an appeal on a question of law with leave of the court. This criticism can be dealt with by providing for expanded grounds of appeal in the arbitration agreement.

- No Regulation - There is also a concern over the ability and qualifications of arbitrators, as they are currently not regulated. Lawyers have also expressed concern that arbitrators are not legally trained and that the rules of evidence do not apply in arbitrations. Again, these concerns can be dealt with in the selection of rules to govern the conduct of the arbitration and in the selection of an arbitrator. ${ }^{31}$

- Credibility - Arbitration may not be the best format for dispute resolution where the key issues concern matters of credibility.

- Not Bound by Precedent - The principle of stare decisis does not apply to arbitrations, with the exception of labour arbitrations, rendering outcomes at arbitration difficult to predict.

- No Summary Procedures - Motions, such as summary judgment, permitting early disposition of cases are rarely available in arbitration. However, parties could agree to an expedited procedure similar to a summary judgment procedure or elect a documents only arbitration.

Comments of panellists and participants taking part in the Ninth Annual Labour Arbitration Conference, Calgary, Alberta, June 1991. Susan Cassidy, Director, Human Resources, says for a typical one day hearing including preparation time and Award writing time, the cost is probably an average $\$ 15,000$ per side, or a total of $\$ 30,000.00$, in her paper entitled "Legal Counscl: Help or Hindrance," presented to the 10th Calgary Arbitration Conference, 1992; S.R. Goldberg, "The Mediation of Grievances Under a Collective Bargaining Contract: An Alternative to Arbitration" (1982) 77 Nw. U.L. Rev. 270 at 281.

This incentive stems from the fact that arbitrators' jobs depend on their reputations as decision makers and there may be incentive to favour the party that is most likely to require arbitration again. Alternatively, the arbitrator may be thinking: "I found against this party in my last 3 arbitrations, I better find in their favour this timc or I won't be asked back." Finally, the arbitrator may try to please all sides and render a "down the middle award." Comment of Board of Examiners, Alberta Arbitration \& Mediation Society, January 1994.

31 The Arbitrators and Mediators Institute of Canada Inc. has been qualifying arbitrators as Chartered Arbitrators based on level of experience since 1988. 
There are legal issues on which no valid arbitration can take place: ${ }^{32}$

(a) matters involving criminal liability;

(b) disputes based on fraud;

(c) disputes involving constructive fraud and contracts induced by duress through fraudulent misrepresentation;

(d) applications to have contracts set aside for mistakes going to the root of the agreement;

(e) conspiracy and defamation..$^{33}$

Other than these types of issues, any matter can be arbitrated. Therefore, the decision as to whether or not to arbitrate depends entirely upon the lawyer's and client's assessment of the case, how quickly a decision is needed or wanted and the procedure with which the client is most comfortable. The decision of whether to arbitrate need not be an all or nothing decision. Certain issues can be arbitrated, leaving other issues to proceed by way of negotiated agreement or trial. For example, the issues submitted to the arbitrator may be limited to certain pieces of property, leaving the disposition of other pieces of property to agreement. Furthermore, the parties may agree in advance on the division of proceeds, leaving valuation up to the arbitrator to decide. The uses and usefulness of arbitration are limited only by the creativity of the parties and their counsel.

\section{MED/ARB}

A further alternative which has been of increasing use over the last number of years in resolving disputes and which is specifically provided for in the Arbitration Act (s. 35 ), is a process called med/arb. This is a process whereby an individual is appointed to arbitrate the issues in dispute. Prior to rendering the award, the arbitrator attempts to facilitate negotiations between the parties and to assist them in resolving some of the issues directly between themselves. If all of the issues are resolved through mediation, then the arbitrator renders an award parallel to the agreement reached (s. 36 of the $A c t$ ). If only some of the issues are resolved through mediation, then the unresolved issues are decided by the arbitrator and the issues agreed upon between the parties form the balance of the binding award. If the parties are able to settle none of the issues through mediation, then the arbitrator simply renders an award as he or she would do in any arbitration. This dual process provides the parties with one last opportunity to negotiate, yet it does not delay a final resolution of the dispute. There are many variations to the med/arb process which should be investigated.

A. Walton \& M. Victoria, Russell on the Law of Arbitration, 20th ed. (London: Stevens \& Sons, 1982) at 22-28; and Lord Hailsham, ed., Halsbury's Laws of England, 4th ed., vol. 2 (London: Butterworths, 1991) at para. 503. 
The perceived benefits of med/arb are as follows:

- Cost and Time Savings - If mediation is unsuccessful, no time or money is lost because the dispute is immediately resolved through the decision of the arbitrator.

- Encourages Negotiation - Parties in dispute often do not negotiate enough (or at all) because the dispute tends to escalate emotions, which is a disincentive to getting together and discussing the problem with a view to resolving it. Also, this step may be pushed aside and overlooked because it takes a lot of work and preparation for negotiations. The med/arb process incorporates negotiation as a step within the process thereby requiring less specific preparation.

- Informed Negotiations - The med/arb process provides the parties with one final opportunity to negotiate a resolution on a fully informed basis.

- Less Posturing - It is perceived that the parties may posture less and attempt wholeheartedly to reach an agreement with med/arb, because if they do not reach an agreement one will be immediately imposed; ${ }^{34}$ therefore, the negotiations tend to be more effective.

- Better Results - The results reached through the med/arb process may be better than would be achieved through arbitration alone. The parties have indicated through mediation what their needs are and this may enable the arbitrator to come up with a more reasoned and predictable result that more creatively meets the parties' needs. ${ }^{35}$ This is, however, also identified as a criticism of med/arb.

- $\quad$ Success - An experiment conducted in Buffalo, New York approximately eight years ago comparing mediation, med/arb (same neutral) and mediation with a mediator and then arbitration with a different individual, found that med/arb (same neutral) was the most successful process. ${ }^{36}$ The study found that there was greater disputant satisfaction and more agreements with the med/arb process than with the others. ${ }^{37}$ Further it found that with med/arb, the disputants also: 185 at 186; and N.B. McGillicuddy, G.V. Welton \& D.G. Pruitt, "Third-Party Intervention: A Field Experiment Comparing Three Different Models" (1987) 53:1 Journal of Personality \& Social Psychology 104 at 110.

37 The American med/arb specialists in the labour area (interest med/arb) where this process has been used primarily, indicate that of the literally hundreds of issues involved in these cases, less than a dozen had to be finally arbitrated by the med/arbitrator as the rest were agreed to in mediation: see Kagel, supra note 34 at 185. 
(a) engaged in more problem solving;

(b) were more conciliatory;

(c) came up with more new solution ideas;

(d) made more concessions;

(e) were less hostile; and

(f) were less competitive with one another than in the other processes.

The observers in the study also noted greater motivation to reach agreement and to impress and follow the mediator with med/arb. It was thought that this may have been due to fear of losing control over one's fate in the event of arbitration or simply out of a natural respect for decision makers.

The perceived disadvantages to the med/arb process are as follows:

- Mediation Tainted - The parties may not find the mediation a "safe place to negotiate" as they are aware that if an agreement is not reached, the mediator will be rendering an award which is final and binding. Accordingly, the parties may not be as open and frank in their discussions as is necessary for successful mediation. ${ }^{38}$

- Poor Decision Making - The focus in mediation is on understanding the needs of each of the parties in dispute and attempting to fashion a creative settlement whereby each party gives up what he values less in return for what he values more. The focus of arbitration is the presentation of evidence and arguments by each side with a decision then being rendered by the arbitrator based upon the merits of the case. Information as to the party's needs and what they may be prepared to concede should be irrelevant to an arbitrator's decision. It may be difficult for the arbitrator to ignore this information after having obtained it during the mediation phase of the arbitration. More importantly, it may be difficult for the parties to accept that the arbitrator has been able to ignore this information in his or her decision making. ${ }^{39}$

- Informal for Arbitration - A very sophisticated or clever party may be able to influence the ultimate decision of the arbitrator by manipulating the informal, consensual mediation stage of the process. ${ }^{40}$

Folberg \& Taylor, supra note 17 at 277.

L.L. Fuller, "Collective Bargaining and the Arbitrator" in Proceedings of the 15th Annual Meeting, National Academy of Arbitrators (Pittsburgh, 1962) 29; McGillicuddy, Welton \& Pruitt, supra note 34 at 111.

Folberg \& Taylor, supra note 17 at 277. 
Clearly the med/arb process works well, and safeguards may simply be needed to avoid the disadvantages of med/arb. Of paramount importance in considering the $\mathrm{med} / \mathrm{arb}$ alternative is the med/arbitrator who is selected. The Society of Professionals in Dispute Resolutions (SPIDR) Ethical Standards of Professional Responsibility state that: "The use of more than one dispute resolution procedure by the same neutral involves additional responsibilities." The individual selected must be skilled in both the process of mediation and arbitration and must understand the risks inherent in the $\mathrm{med} / \mathrm{arb}$ process.

\section{PRE-TRIAL CONFERENCE}

Rule 219 of the Alberta Rules of Court ${ }^{41}$ provides the court with the power to meet with litigants and/or their counsel in any action and to assist them to more quickly resolve the issues between them. The rule was expanded in June of 1994 with a decision to implement the proposed rule for a period time through the use of a Practice Note so that the effect of the changes can be monitored before the Rules of Court are actually amended. The deficiency being addressed by the amended rule is the fact that at present the litigation process is too slow and expensive, due largely to excessive or wasteful pre-trial activity. ${ }^{42}$ The new rule was intended to shift the emphasis away from a conference focused solely on the trial and toward a process of judicial management that embraces the entire pre-trial phase, especially interlocutory applications and discovery. ${ }^{43}$ The key components of the revised rule are settlement facilitation and judicial case management as a catalyst for more efficient litigation and effective control of procedural abuses. In Saskatchewan, the Court of Queen's Bench has experienced an 85 percent success rate with their new Pre-Trial Conference rules. $^{44}$

Stemming from the new Pre-Trial Conference rule, particularly the need for adopting special procedures for managing potentially difficult or protracted actions that involve complex issues, multiple parties, difficult legal questions or unusual proof problems, the Very Long Trial Project was initiated. The Project is aimed at reducing the drain on judicial and court resources posed by very long civil trials of over forty days. The proposal requires mandatory case management from the close of pleadings for such actions, a case timetable and significant consequences for non-compliance, not only in terms of the outcome of the action but also financially against the parties and their counsel. This project is still in the developmental stages.

The opportunities for using the various provisions provided for in the new rule 219 are limitless. A further exploration of the opportunities which this new rule provides and the extent to which they have been utilized is worthwhile.

4t Alberta Rules of Court.

42 Report of the Civil Practice Steering Committee (January, 1993) at 3.

4 Comments to the suggested draft provisions to Rule 219, March 1993.

44 Comments from members of the Saskatchewan Court of Queen's Bench attending the Pre-Trial Conference Workshop hosted by the Canadian Judicial Centre in Saskatoon, Saskatchewan in November of 1990. 
The Trial Division of the Federal Court of Canada has also adopted case management procedures to expedite cases and make better use of judges' time. The Associate Chief Justice is prepared to designate a single judge to hear all interlocutory motions in a complex case on the written request of counsel, or on the recommendation of a judge hearing a motion in the proceedings. ${ }^{45}$

The benefits of a settlement-oriented pre-trial conference are as follows:

- Time and Cost Savings - A 1 percent increase in pre-trial dispositions from 95 percent to 96 percent produces a 20 percent reduction in trial load. ${ }^{46}$

- Better Trial Preparation - Counsel are forced to assess and deal with the weaknesses and strengths of their client's case prior to trial, thereby making counsel better prepared for trial if no settlement is reached.

- Litigants Involved - The client's direct input and immediate feedback from an impartial judge leaves the litigants with a positive attitude towards the entire process. ${ }^{47}$

- Day In Court - The litigants feel that they have had the opportunity to present their case to a judge.

- Focus on the Real Issues - The settlement conference will directly or indirectly force lawyers to be less adversarial and to be less concerned with the technical and rigid aspects of the law. Rules and regulations will take a back seat to the real issues effecting the litigants. ${ }^{48}$

- Reduction in Settlement Discussions On the First Day of Trial - The trial judge will not have to discuss settlement with counsel immediately before or during the trial, as counsel have had an opportunity to explore the issues, narrow down the facts in disagreement and discuss settlement before the pretrial judge. Indeed, many judges perceive that such settlement discussion immediately before or during trial negatively affects their appearance of impartiality and leads to greater dissatisfaction with the outcome at trial. ${ }^{49}$

Federal Court of Canada, Circular No. 2/93, 19 February 1993.

46 The Honourable Mr. Justice R.E. Holland, "Pre-Trial Conferences in Canada" (1987) 7 Adv. Q. 416 at 417. 
Some of the drawbacks which have been identified with settlement focus pre-trial conferences include the following:

- Fewer Attempts at Direct Settlement - The expanded use of settlement oriented pre-trial conferences may lead to a reduction in pre-pre-trial settlement efforts directly between counsel. ${ }^{\text {so }}$

- Pre-trial Settlement Conferences Actually Increase the Court's Workload Also, it appears from empirical evidence that allocating more judicial time to settlement functions can actually slow down the overall speed with which the court can dispose of a case, because more judicial time is needed per case. ${ }^{\text {sI }}$

- Abuse by the Court of its Settlement Role - There is also the potential for abuse of the court's role in pre-trial settlement conferences as Church reported. ${ }^{52}$ Overzealous judges may exercise undue influence on a final settlement, often without adequate knowledge or understanding of the facts of the case.

"More and more counsel seem to see the pre-trial conference or the courthouse steps as the natural place to settle a case. Indeed, one experienced Toronto counsel advances the following theory: before the advent of pre-trial conferences, settlement discussions almost invariably took place at the end of discoveries; now, there is a tendency to wait until the pre-trial before discussing settlement," per D. Stockwood, "The Private Court," in P. Emond, ed., Commercial Dispute Resolution (Aurora: Canada Law Book Inc., 1989) 226; often lawyers fail to discuss even an Agreed Statement of Facts prior to a pre-trial, per Spencer, "Congestion in the Courts, Trial \& Error, the British Columbia Experience" Annual Meeting Papers of the Canadian Bar Association (Ottawa, 1989) c.1.05. M. Galanter also comments "[I]t does appear that cases that once might have been settled by negotiations between opposing counsel are now settled with the participation of the judge. We have moved from dyadic to mediated bargaining" in "The Emergence of the Judge as Mediator in Civil Cases" (1986) 69 Judicature 257 at 262. "By the fall 1990 sittings [of the Saskatchewan Court of Queen's bench], parties who were ready for trial in five of the major judicial centres and who were not caught by a pre-trial requirement could have had a trial date on or before the next available pre-trial date," per Epp J.A., "Saskatchewan Pre-Trials: An Empirical Record and Proposed Amendments" (1991) 55 Sask. L. Rev. 43 at 69; J. Church also notes in Justice Delayed (Williamsburg, Va.: National Centre for State Courts, 1978) at 33:

Those courts that exert the most effort in settling cases do not necessarily dispose of more cases per judge than those courts where less judicial settlement effort is expended. The only obvious relationship in the table is the perfect inverse relationship between amount of court settlement activity and median disposition time. The most settlement-intensive courts are the slowest courts. We are not in a position to assert causality here. It seems clear, however, that fast courts on civil case processing need not be 'settling' courts.

The Federal Judicial Center's study on federal trial courts reached a similar conclusion: S.Flanders, Case Management and Court Management in United States District Courts (Washington, D.C.: Federal Judicial Center, 1977) at 37:

Judicial participation in settlement produces mixed results. A limited role may be valuable, but data suggest that a large expenditure of judicial time is fruitless.

Ibid. at 76-77. Church's findings were confirmed by American researchers J.A. Wall, L.F. Schiller \& R.J. Ebert, "Should Judges Grease the Slow Wheels of Justice? A Survey on the Effectiveness of Judicial Mediary Techniques" (1984) 8 Am. J. Trial Advocacy 83 at 110-12. 
- No Control Over What Can be Put Before the Judge - The judge will have available all the documents which each side believes the judge ought to see, often whether or not admissible at trial..$^{53}$

- Credibility Cannot be Addressed - The judge at a pre-trial conference has limited opportunity to assess credibility of the witnesses. ${ }^{54}$

- Cost Savings to Client Limited - To be effective, counsel must be well prepared and thus the client is really only spared the cost of witnesses and counsel appearing at trial.

\section{EARLY NEUTRAL EVALUATION}

This process involves a consultation with a respected attorney appointed by the court. The attorney listens to the case presented by each side and helps the parties find areas of agreement that identify the core issues in dispute prior to trial. ${ }^{55}$ The neutral may assess each disputant's case and make an evaluation as to the likely outcome of litigation. "The federal court for the Northern District of California in San Francisco sends up to 300 cases a year through [this] settlement program" with up to 40 percent of those cases settling. ${ }^{56}$ Early neutral evaluation is also being utilized by the Alberta Human Rights Commission in its attempt to increase effective resolution of disputes. ${ }^{57}$

\section{THE MINI-TRIAL}

The mini-trial is not really a trial at all but a combination of negotiation, mediation and adjudication processes. In this process, the parties select a mutually acceptable adjudicator to preside over an abbreviated hearing and to render an opinion as to the likely outcome of the matter at trial. In Alberta, the adjudicator is generally a member of the Court of Queen's Bench. The adjudicator has no authority to make a binding decision other than on procedural matters relating to the mini-trial. In this process, counsel for each disputant makes a summary presentation of their best case to the adjudicator. In some instances high level business executives from each of the disputing corporations also hear the presentation and may meet after the summary presentations to attempt to negotiate a resolution of the dispute. The adjudicator will render an opinion as to the likely outcome of the matter at trial if the business executives are unable to negotiate a settlement, or as an impetus towards negotiating settlement.

The effect of a mini-trial process is to convert a dispute from a legal problem to a business problem by putting the resolution of the dispute back into the hands of the disputants directly involved. The goal is a sensible resolution to the dispute crafted by

C. Kloppenburg, "Criteria for Evaluating Settlement Pre-Trial Conferences," Bar Notes (March 1990) at 3.

Kloppenburg, ibid.

Goldberg, Green \& Sander, supra note 3 at 62.

M. Galen, "Guilty! Too Many Lawyers and Too Much Litigation: Here's A Better Way" Business Week (13 April 1992) 60 at 64.

Comments of Audrey Dean, Legal Counsel, Alberta Human Rights Commission, March 1995. 
those most experienced in doing so and with the greatest knowledge of the situation those involved. Those are the individuals who are often better able to assess the risks and costs involved in litigation and to see where creative solution ideas may lie. The advantage which the mini-trial offers over direct negotiations is that each side has had the opportunity to hear the best case for and against each side. This opportunity gives them the most informed perspective from which to enter into negotiations, particularly if armed with the advisory ruling of the adjudicator.

Two different forms of the mini-trial have emerged, the private mini-trial and the traditional mini-trial. The private mini-trial is focused on ensuring that business executives from the disputing parties are present for the summary presentations, and it includes negotiations prior to an advisory opinion as an essential element to the minitrial process. The judicial mini-trial is focused on the advisory ruling by the adjudicator which is hoped to be an impetus towards settlement negotiations between the parties. The judge's comments are intended to provide an objective appraisal of the case to promote settlement. Both processes have enjoyed tremendous success. The private minitrial tends to be more appropriate for commercial lawsuits involving corporations. The judicial mini-trial has enjoyed tremendous success with a wide variety of issues including family matters, personal injury matters and wrongful dismissal.

The advantages to a mini-trial including the following:

- Creative Business Solutions - The goal of the mini-trial is settlement arrived at by business representatives with full knowledge of the strengths and weaknesses of their case. It calls upon the expertise of counsel in presenting the best possible case for each side and of the business representatives to negotiate a creative business-oriented resolution to the dispute. The resolution is not based upon legal rights and responsibilities; it is based, from each companies' perspective, on the best corporate deal which they could craft with the opposing side in light of the existing dispute. The goal during these negotiations is to expand the dispute resolution options to the entire relationship between the parties and not just the dispute which exists between them. This leads to more creative resolutions.

- Cost Savings - The cost savings afforded by successfully utilizing the minitrial procedure are found both in terms of money expended and hours saved. The cost of a successful mini -trial is about one tenth of what litigation costs would be were the case to go to trial. ${ }^{58}$ Because of the short time allotted for the mini-trial from start to finish, the amount of time spent on the process by lawyers, in-house counsel and employees is a fraction of that which would be spent in taking the matter to trial, depending of course on how soon the minitrial procedure is initiated. Furthermore, because the mini-trial process is 
abbreviated and forces counsel to focus on the main issues, it can save money by narrowing the areas of focus for counsel if the mini-trial is unsuccessful.

The drawbacks of the mini-trial process include the following:

- Cost and Time - If the mini-trial is unsuccessful, it can increase the cost and time of a lawsuit.

- Need for Trust - The mini-trial process requires some level of trust among lawyers and executives and accordingly parties may not be able to come up with a means for conducting a mini-trial with which they can be comfortable. In such situations the neutral advisor may be able to help by assisting the parties in their negotiations as to process.

- Credibility of Witnesses - The minimal use of witnesses and crossexamination of witnesses means the credibility of witnesses cannot be tested. Furthermore, there may be impediments to enforcing the duty to tell the truth by the usual sanction of prosecution for perjury because of the confidentiality of the mini-trial.

\section{SUMMARY JURY TRIAL}

The summary jury trial procedure consists of proceedings, usually no longer than half a day, wherein counsel for each party presents its case to a judge and jury of six. Senior executives from each side, having authority to settle, are in attendance. After the presentations, the jury receives an abbreviated charge by the presiding judge and retires for deliberations and a decision. A settlement conference is usually scheduled for a few weeks later enabling each of the parties to assess their position in light of the jury's response to their case..$^{59}$ Immediately after the jury's verdict, the executives are invited to stay and discuss with the jurors the basis upon which the decision was reached. The purpose of the discussion is to assist the executives in the settlement negotiations following the summary jury trial.

The perceived advantages of the summary jury trial are as follows:

- Success Rate - The success rate of summary jury trials has ranged from 50 percent to 90 percent, depending upon the jurisdiction. ${ }^{60}$ The longer the trial, the greater the potential value of a summary jury trial because the jury has the entire fact situation presented to them in a short period of time, as opposed to weeks or months of evidence.

- Effective Negotiations - The summary jury trial provides a good basis upon which negotiations can commence as the parties obtain an informed

(1) Henry \& Lieberman, supra note 58 at 124. 
understanding of the limits of both side's positions and how those would appear to a jury.

- Preparation - Counsel prepare themselves well before trial, thereby opening the possibility for early settlement, even if the summary jury trial is not successful.

The perceived disadvantages and limitations to the summary jury trial procedure are as follows: ${ }^{61}$

- Cost and Delay - If unsuccessful, it adds delay and expense to the case.

- Strategy Revealed - Counsel must reveal their trial strategy early in the litigation.

- $\quad$ Credibility of Witnesses - Where credibility is at issue, the summary jury trial may not be the most effective way of resolving the dispute as jurors cannot test the truth of counsel's summary of the witnesses' testimony.

\section{REFEREES}

A referee process is where a case is heard by an officer of the court but not by a judge. It is heard in a manner similar to a judicial proceeding and then a recommendation is made to the court. The court may accept, reject or vary the recommendation. In Alberta, although referees can be appointed under the Rules of Court, they have seldom been used. Under rule 403, official referees include masters in chambers, clerks, persons appointed by the Lieutenant-Governor-in-Council and persons appointed with the consent of all parties to the lawsuit. Section 403(d) was added in 1991 to encourage wider use of referees in Alberta after the publication of the Report on Referees by the Alberta Law Reform Institute. ${ }^{62}$

Any question of fact may be sent to a referee in Alberta. A judge could ask a referee to. ${ }^{63}$

(a) sort out complicated accounts in a mortgage or partnership case;

(b) investigate deficiencies or delays, and resulting damages in a construction case;

(c) investigate and report on the damages in a personal injury suit;

(d) investigate the worth or loss of a going business;

(e) determine whether a vendor can make good title; 
(f) look into the means and needs of a spouse seeking or paying maintenance;

(g) compute the lien fund in precise entitlement in a builder's lien action.

Proceedings before a referee are usually conducted in much the same manner as those before a judge. The referee is allowed to get advice or directions from the court on any point of law. Constitutional objections under Section 96 of the Constitution Act, $1982^{64}$ regarding the referee have not been upheld on the basis that the referee only investigates and reports while the court makes the actual judgment. ${ }^{65}$

The perceived benefits or advantages of the referee system are as follows:

- Expertise - The parties or the court may choose a third party with expertise in the area of dispute.

- Efficiency - Referees with expertise may be able to save time and, therefore, costs. Counsel can also request a shortened time period for receipt of the final report in order to speed up the process.

- Flexibility with Rules and Procedures - If the parties want a formal process, they may agree to utilize such a process. In the same manner, if they wish a more informal procedure, such as is utilized in arbitration, they may agree upon that as well, subject to rule 425. Basically, parties can design rules of evidence and procedure which meet their specific needs.

- Courts Focused - The administration of justice will become much more efficient if the courts focus on legal questions as opposed to factual issues. ${ }^{66}$

The perceived disadvantages of referees are time and the chance that the report of the referee may not adopted by the court.

\section{PRIVATE COURT}

Private courts are exactly that, a private adjudicatory system outside of the public judicial system. They originated in the United States, where they have become very popular as an alternative to the public court system. In 1988, a group of Toronto lawyers formed a Canadian Private Court system called "Private Court." Private Court is an adjudication service aimed at settling business lawsuits. It offers mediation, arbitration and other forms of dispute resolution such as mini-trials in a form which is similar to the traditional court system. ${ }^{67}$ Private Court handled forty-seven claims in

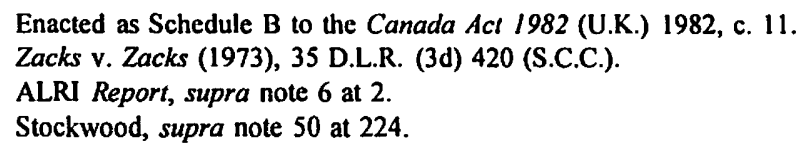


the Olympia \& York restructuring described by David Stockwood in The Lawyer's Weekly as "the most striking success in Ontario dispute resolution history." ${ }^{168}$

The advantages to the Private Court system over the public judicial system are as follows:

- Convenience - The parties can schedule the place, date and time of the hearing around the witnesses', lawyers' and judge's schedules.

- Flexibility - The parties can create a procedure with which everyone is comfortable, be it formal or informal, etc.

- $\quad$ Speed - The parties can be at trial within months or even weeks of when the dispute arose. This is probably the major reason private judging is chosen in California where a matter can take $3 \frac{1}{2}$ to $4 \frac{1}{2}$ years to get to trial. The evidence is also fresher with increased speed in bringing the matter to trial. ${ }^{69}$

- Confidentiality - Where trade secrets or celebrities are involved, confidentiality is a strong draw. For example, Johnny Carson and the National Broadcasting Corporation chose to resolve a contract dispute by a private judge with express confidentiality provisions placed on the judge. ${ }^{70}$

- Informality - The parties can choose someone familiar with the subject matter in dispute. This in and of itself may also lend more credibility and acceptance of the final decision. ${ }^{71}$

The disadvantages to the Private Court dispute resolution system include the following:

- Cost - The parties must pay for the system, estimated at about $\$ 2,000.00$ per day for the adjudicator alone. ${ }^{72}$

R. Klein, "Toronto's Private Court Offers Binding and Non-Binding Resolution Procedures" The Lawyer's Weekly (27 August 1993) at 13.

T.S. Vangel, "Private Judging in California: Ethical Concerns and Constitutional Considerations" (1988) 23 New England L. Rev. 363 at 371.

B.F. Christensen, "Private Justice: California's General Reference Procedure" (1982) 1 Am. Bar F. Res. J. 79.

Tannis, supra note 4 at $227-28$.

One lawyer estimated that the use of a private judge enabled a case that would have taken $2 \frac{1}{2}$ years and cost $\$ 250,000.00$ to take only four months and cost $\$ 50,000.00$, per L.S. Janojksy, "The 'Big Case': A 'Big Burden' on our Courts" (1980) Utah L. Rev. 719 at 725; another lawyer commented that private judging "saved 80 percent of the delays, 80 percent of the legal fees and 80 percent of the aggravation" associated with taking a case through the traditional system, per G.C. Hill, "Rent-a-Judge: California is Allowing its Wealthy Litigants to Hire Private Jurists" The Wall Street Journal (6 August 1980) 1 at 15. 
- Discrimination - The Private Court system has been criticised for creating two tiers of justice because it is not equally accessible to all citizens. ${ }^{73}$

\section{NEUTRAL EXPERT FACT FINDING}

With very complex scientific, sociological, technical, economic and business disputes resolution usually hinges on the technical conclusions of experts. Some litigants have successfully appointed one neutral technical expert to examine and evaluate the disputed facts and key issues and render a non-binding report to both of the parties. ${ }^{74}$ If an expert can be appointed by all parties on the basis of his or her qualifications to render an impartial,common, non-binding opinion, the parties may be more inclined to modify their assessment of the case than if the expert is retained and instructed by the other side. Furthermore, because experts are influenced by value judgments and philosophical preferences, in this approach the parties can orient the expert in a way that they both agree upon before the opinion is rendered, thereby leaving the value and philosophical judgments with the parties. In some cases, the parties have agreed that the resolution be binding.

The criticism of this process is that it takes the control of the litigation and resolution of the dispute out of the hands of the parties and into the hands of the neutral expert. ${ }^{75}$ Ways of effectively utilizing experts within the context of dispute resolution processes is an area that has not yet been fully explored; it offers tremendous potential for the effective resolution of disputes.

\section{CONFIDENTIAL LISTENING}

A variant of this form of dispute resolution is confidential listening. In this process, the parties submit their confidential settlement positions to a third party neutral who then informs them of whether their positions are within a negotiable range. The confidential listener does not advise one side of the other side's position, but only whether the parties could negotiate a settlement. If the parties are not within a settlement range, they may attempt again to submit a confidential settlement position to determine whether a settlement range can be reached. ${ }^{76}$

\section{APPRAISAL/VALUATION}

Another form of $A D R$ is the appraisal or valuation procedure where an appraiser, valuator or expert is appointed to identify the matters in dispute between parties and to resolve them. This individual is not usually characterized as an arbitrator because he or she is often not resolving a dispute, but simply valuing assets, to supply a necessary 
component of the contract. ${ }^{77}$ The differences between an arbitrator and an appraiser or valuator are as follows:

(a) a party could still sue a valuator/appraiser in negligence. If a person is characterized as an arbitrator then, absent fraud or bad faith, the arbitrator cannot be sued, ${ }^{78}$

(b) there are fewer formalities in decision-making required with a valuator or appraiser. $^{79}$

(c) the expert valuator or appraiser still has a duty to be impartial, which is judged by the same standards as other decision-makers i.e., does a reasonable apprehension of bias exist? ? $^{80}$

(d) if the expert is not found to be impartial, his or her decision can be set aside with the appraisal process; ${ }^{81}$

(e) the appraisal/valuation process does not have the finality offered by the Arbitration Act, in terms of enforcement.

It is important to think about these implications when considering whether to appoint a valuator/appraiser or an arbitrator in a contract.

\section{SETTLEMENT WEEK}

In recent years, the Insurance Bureau of Canada (IBC) has hosted one or two-day settlement conferences across Canada which have become very popular. ${ }^{82}$ IBC hosts about eight to ten conferences per year in major cities; it books a block of rooms for its members and opens the doors to lawyers with outstanding claims in an attempt to settle or move forward on as many files as possible. At the December 1991 conference in Toronto, about 1,000 files were dealt with and 71 percent were settled, a common outcome of these events. ${ }^{83}$ Most claims dealt with during Settlement Week are relatively minor personal injury claims.

\section{THE OMBUDSMAN}

An ombudsman is also often used to resolve grievances and disputes outside of the judicial system. The first classic ombudsman appeared in the Swedish Constitution in

$n \quad$ See Sport Maska Inc. v. Zittrer, [1988] 1 S.C.R. 564.

78 Ibid.

79 See Rye Farm Co. v. British Oak Ins. Co., [1924] 3 D.L.R. 706 (Alta. C.A.).

see McPeak v. Herald Insurance Co. (1991), 115 A.R. 83 (Q.B.).

nIbid.

22 "Settle Fast" Canadian Lawyer (April 1992) 50.

3) A similar rate of settlement was achieved by the New South Wales Supreme Cour during Australia's first ever "Settlement Week" in October 1991: See World Arbitration and Mediation Report. 
the early 1800 s (the word in Swedish means "representative of the people"). ${ }^{84}$ Serious interest in the ombuds office began in the United States in the 1960s and grew only slowly until the 1980s. Since then, there has been tremendous growth in the interest and utilization of ombudspersons. Ten years ago, there were only about 500 ombuds offices, now there are over 10,000 - twenty times as many. ${ }^{85}$

Not only is the office being used publicly throughout Canada to correct abuses of public administration, but also privately within corporations, hospitals, universities and other institutions as a means of correcting organizational abuses and resolving internal disputes. ${ }^{86}$ The public ombudsman is not a public servant but an independent officer of the legislature acting as a non-partisan third party fact finder. The public ombudsman has the power to investigate, criticize and publicize a decision or recommendation made or any act done or omitted in the course of administration of governmental organizations (ministry, commission, board, etc.), which affects any person or body of persons in his or its personal capacity. The purpose of the ombudsman is to ensure proper government administration and fairness for the public in their dealings with government. The ombudsman cannot review the decisions of judges, the functions of any court of law, the deliberations and proceedings of executive counsel or any committee thereof and has no power to reverse administrative actions. ${ }^{87}$ The ombudsman's role is restricted to making recommendations, the scope of which is virtually unlimited.

The corporate ombudsman, sometimes also referred to as liaison, work problems counsellor, or personnel communications officer, is a neutral or impartial manager within a corporation, who may provide confidential and informal assistance to managers

M.P. Rowe, "The Corporate Ombudsman: An Overview and Analysis" (1987) 3 Negotiation Journal 127 at 138-39.

8s Comment of Mary Rowe, Ombudsperson at MIT, at the Second National Grievance Mediation Seminar (May 1992, Washington, D.C.).

86 In British Columbia, MacMillan Bloedel has established a complaint review system involving an internal ombudsman who will investigate employee concerns and help find solutions: J. Sanderson, "Mediation a Good Alternative to Ritualistic Legal Warfare" Financial Post (19 August 1991) 9; charges of biased reporting by the CBC have lead to the creation of an ombudsman's office, with branches in Toronto and Montreal, which will have the power to independently review and investigate complaints: D. Retson, "CBC Creates Ombudsman's Post to Answer Charges of Bias" The [Edmonton] Journal (5 June 1991) A3; the need for a shareholder ombudsman to "arbitrate disputes and dissenting shareholder spats" has also been called for in Canada to assist shareholders in pursuing their rights under the law: Francis, "Demonstrating the Need for a Shareholder Ombudsman" The Financial Post (11 April 1988) 16; a government ombudsman to sort out loan disputes between small and medium sized businesses and banks was recommended by a federal commons committee, I. Austen, "Bank Loan Ombudsman Suggested" The [Edmonton] Journal (19 October 1994) El, and the University of Alberta has a Student Ombuds Service (SOS) to investigate and assist students in resolution of grievances against both the $U$ of $A$ and Students Union (funded through Student Union fees). Also the $U$ of A Hospital in Edmonton has had a full time patient ombudsman since 1986. Some large American companies with an ombudsman for employee disputes are Control Data, Federal Express, IBM, McDonald's Corporation, American Optical Company and the Bank of America: Rowe, supra note 84 at 109. 
and employees in resolving work-related concerns, or who may serve as a counsellor, go-between mediator, fact finder or upward feedback mechanism. Usually the ombudsman is a high company official with considerable respect at the highest management levels and whose office is located outside line management structures. ${ }^{88}$ Most ombudsmen report to the CEO or someone close to the CEO.

The ombudsman is generally empowered to talk to anyone to uncover the facts around a problem or dispute and to make a recommendation to senior management about how to dispose of the case. Their duty is not to senior management, but to the facts and recommendations made. Interestingly enough, surveys have shown that some people within an organization will choose to see an ombuds instead of an employee relations officer because the ombudsperson is seen as neutral, the parties do not want the problem (real or imaginary) in their personnel file, the parties are seeking a referral to a counsellor, or the solution requires detailed knowledge of the individual company. ${ }^{89}$ Clearly, the office of the ombudsman is an area which provides tremendous opportunity for dispute resolution in larger institutions and within the public sector.

\section{LITIGATION MANAGEMENT}

Litigation management involves the assessment of cases in litigation from a managerial perspective. There are two aspects of litigation management: litigation analysis and the litigation budget. Litigation analysis is a process of valuing the probable outcomes of various stages of litigation and making an overall assessment of the entire case using decision tree analysis. ${ }^{90}$ The assessments of risk and determinations of probable outcome are all subjective and based on a number of unknown factors, but they do focus both counsel and the client on realistically reviewing every aspect of their case. This type of analysis will assist in making negotiations more effective.

The litigation budget is a financial plan developed at the outset of litigation which identifies and allocates funds for various aspects of the litigation such as specific motions, research, discovery, etc. ${ }^{91}$ The litigation budget may be developed after a litigation analysis is conducted. The process of developing such a budget forces both counsel and the litigant to think about the costs of each step in the litigation process and the likely returns from that expenditure. It may also assist counsel in more effectively assessing the settlement offers made and received.

\section{DISPUTE PREVENTION}

Probably the ultimate aim of alternate dispute resolution advocates is the anticipation and avoidance of future legal disputes or, if they are unavoidable, to plan for their

Rowe, supra note 84 at 127.

Ibid. at 136

9 D. Goldner, "Borrowing a Tool from Business" The American Lawyer (July/August 1986) 12.

91 Goldberg, Green \& Sander, supra note 3 at 51. 
effective resolution. A number of companies have developed both internal and external systems for identifying potential areas of conflict and resolving disputes once they have occurred. For example, organizations are using in-house neutrals or ombudsmen to investigate complaints and mediate among disputing parties as referred to earlier. Furthermore, in the United States over 2,500 major American corporations and their subsidiaries have signed the Corporate Policy Statement on ADR initiated by the Center for Public Resources. Under the policy, these companies pledge to seriously explore negotiation or other forms of alternate dispute resolution when they become embroiled in a dispute with another signatory to the pledge before pursuing full scale litigation. As of 1991, over 600 American corporations and their subsidiaries, a total of about 2,400 companies representing over one-half of the U.S. GNP, had signed the pledge. ${ }^{22}$ Furthermore, as of 1992 over 1,400 law firms had signed the Center's Law Firm Policy Statement on alternatives to litigation. This Policy Statement commits subscribing firms to assure that appropriate lawyers are knowledgeable about ADR and discuss ADR with clients. Recently, similar pledges have emerged in specific industries, such as the food industry, originating out of the Center for Public Resources.

In Canada, a similar pledge for corporations has been developed through the Canadian Foundation for Dispute Resolution. To date, approximately twenty-eight members and $\$ 150,000$ in commitments have been signed to the protocol in Calgary alone since the establishment of the Foundation late in $1994 .{ }^{93}$ With an awareness of the reality of conflict in most situations, pre-emptive steps such as this can set the groundwork for effectively resolving the conflict before it escalates to greater proportions.

\section{CONCLUSION}

Alternative dispute resolution involves methods of resolving disputes other than litigation. The methods are in addition to litigation and are by no means intended to replace litigation. Even the strongest proponents of ADR agree that certain matters must be resolved through the courts. However, we as lawyers must be familiar with the range of alternatives available to adequately and properly serve our clients in this competitive global economy. In the words of Derek Bok, a past President of Harvard Law School:

[Over the next generation] ... society's greatest opportunities will lie in tapping human inclination towards collaboration and compromise rather than stirring our proclivities for competition and rivalry. If lawyers are not leaders in marshalling cooperation and designing mechanisms that allow it to flourish, they will not be at the center of the most creative social experiment of our time."

Center for Public Resources Inc., Current activities of the CPR Legal Program 1991-92 (New York: CPRI, 1992). As a result of utilizing these processes, savings of approximately $\$ 800,000$ per company have been recorded in "Cost Savings," Center for Public Resources.

93 Per Owen Schneider, Canadian Foundation for Dispute Resolution, March 1995.

I.G. Scott, "The Government Perspective," in Alternative Dispute Resolution: What's All the Fuss and Where is it Going? (Toronto: Canadian Bar Association, 1988) at 18. 
XXI. APPENDIX

\section{DISPUTE RESOLUTION CONTINUUM}

Parties Have Most Most Control Over Outcome

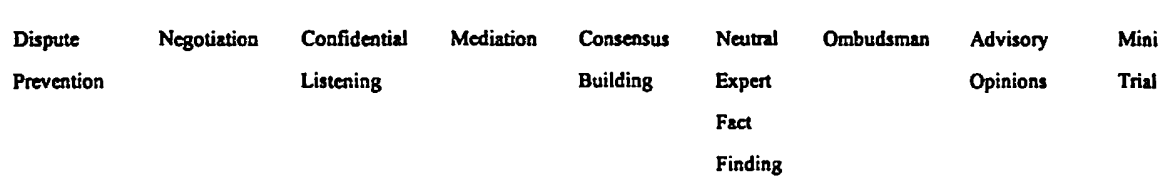

Parties Have Least Control Over Outcome

\begin{tabular}{lllllllll}
\hline Early & Pretrial & Summrsy & Med/Arb & Arbitration & Private & Referce & Litigation & Litigation \\
Neutral & Conference & Jury & & & Judging & & Management \\
Evaluation & & Trial & & & & &
\end{tabular}

